Нероба B. P. (ORCID: 0000-0002-7232-3285);

Національна академія Державної прикордонної служби України імені Богдана Хмельницького, Хмельницький

\title{
Модель сигнатур мін для видових технічних засобів повітряної розвідки
}

Резюме. У статті запропоновано методичний підхід до побудови моделі сигнатури мін для видових технічних засобів повітряної розвідки, що дає змогу визначати сектори спектрального діапазону як відбитих, так і випромінюваних сигналів від мін і ландшафту, на якому вони встановлені, що проходять через “вікна прозорості” атмосфери і можуть бути зареєстровані видовими технічними засобами розвідки безпілотного літального апарата.

Ключові слова: міна; сигнатура; повітряна розвідка; безпілотний літальний апарат.

Постановка проблеми. Аналіз засобів розвідки мін у ЗС України та Державній прикордонній службі (ДПС) України показав, що недоліками наявних на озброєнні наземних технічних засобів інженерної розвідки мін слід вважати їх моральну застарілість в умовах світової тенденції створення та застосування роботизованих комплексів i систем у військовій сфері. Сучасні засоби дистанційної повітряної розвідки мін із застосуванням спеціалізованих безпілотних літальних апаратів (БПЛА) не застосовуються. Це призводить до втрат особового складу інженерно-саперних підрозділів ЗС України. За період виконання завдань у районах проведення АТО/ООС із 2014 року по квітень 2019 року ці втрати склади 125 осіб, з яких 36 загинули, 89 отримали поранення різного характеру [1].

Аналіз останніх досліджень i публікацій. Питаннями, пов'язаними із різноманітними дослідженнями щодо розроблення та застосування БПЛА для виконання завдань розвідки та спостереження, визначення їх тактико-технічних характеристик, обладнання та аеродинаміки займалася низка українських фахівців та вчених: О. Ананьїн, Л. Артюшин, Ю. Даник, I. Даценко, Р. Дмитрук, В. Кириленко, С. Мосов, Ю. Меньшаков, Х. Бурштинська, С. Станкевич та ін. [1-6].

Водночас, ці дослідження носять досить загальний характер і не пов'язані з розвідкою таких малорозмірних об'єктів, якими є міни.

Мета статті. Обгрунтувати методичний підхід до побудови моделі сигнатур мін для видових технічних засобів повітряної розвідки безпілотних літальних апаратів.
Виклад основного матеріалу. Під терміном "сигнатура" у військовій справі слід розуміти набір характеристик випромінюваного чи відбитого ціллю (об'єктом), а також ландшафтом, на якому розташована ціль (об'єкт) сигналу, що реєструється технічним засобом розвідки (спостереження).

Під моделлю сигнатур міни під час ведення розвідки мін із застосуванням видових технічних засобів розвідки (ВТЗР) БПЛА пропонується розуміти набір спектральних характеристик випромінюваних (власних) чи відбитих міною або ландшафтом, де встановлена міна, сигналів, що приймаються різними за призначенням ВТЗР БПЛА [2].

Зазначену модель $Q_{\mu}$ можна описати у функціональному вигляді так:

$$
Q_{M}=f\left(X_{1}, X_{2}, \ldots X_{n}\right),
$$

де $X_{i}, i=\overline{1, n}$ - спектральні характеристики міни у $i$-му піддіапазоні сканування;

$n$ - кількість піддіапазонів сканування.

Під час використання видових технічних засобів розвідки мін кожному діапазону довжин хвиль $\lambda$ електромагнітного спектра відповідатиме $i$-й образ міни на цифровому знімку у вигляді іiі зображення чи зображення контуру місця встановлення міни та іiі маскування на ландшафті (обочина дороги, поле, берег річки, лісова смуга тощо).

Дослідження проведено на прикладі протипіхотної міни ПМН-2 з пластмасовим корпусом.

Протипіхотна фугасна міна натискної дії ПМН-2 має пластмасовий корпус невеликого діаметра - 120 мм. Під час установки міни в грунт чи сніг вона обов'язково маскується (рис. 1-4). 


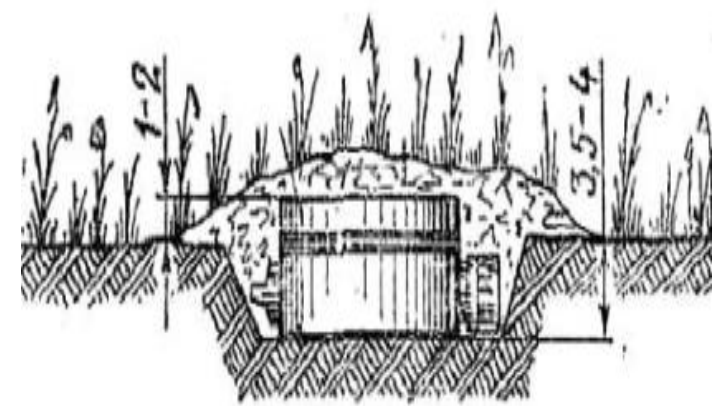

Рис. 1. Схема маскування у грунті міни ПМН-2

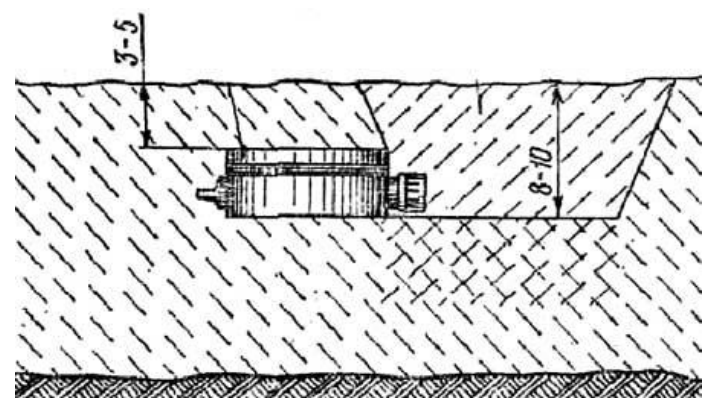

Рис. 2. Схема маскування в снігу міни ПМН-2
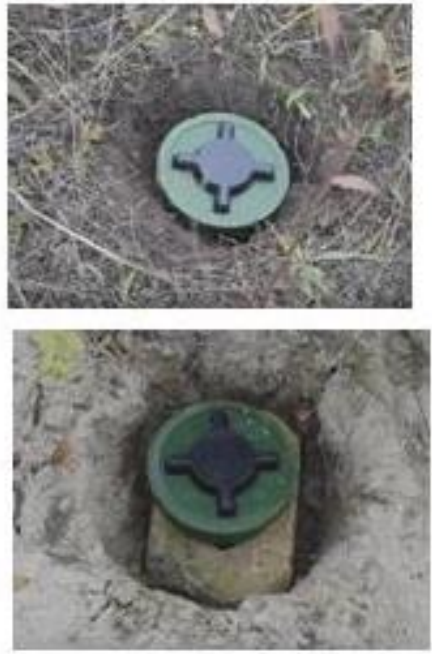
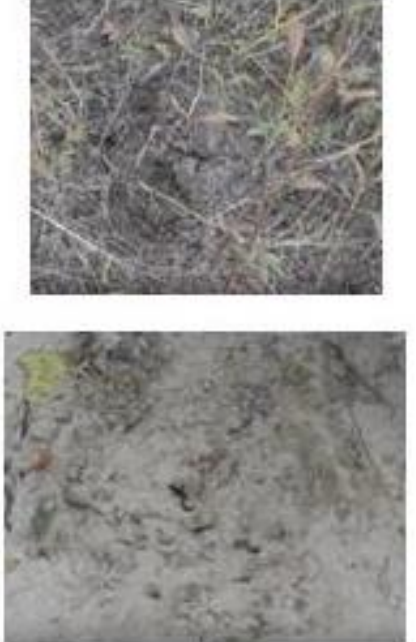
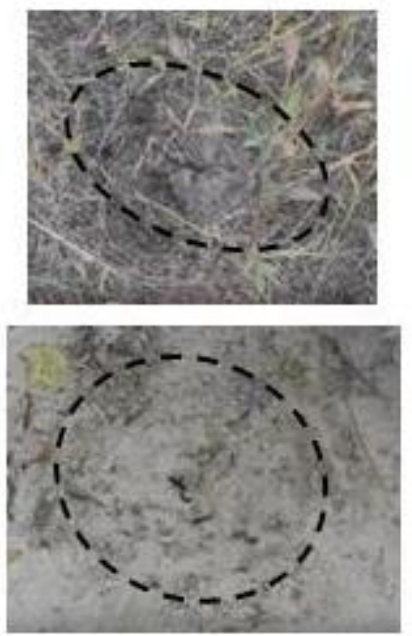

Рис. 3. Зображення установки міни ПМН-2 у грунт
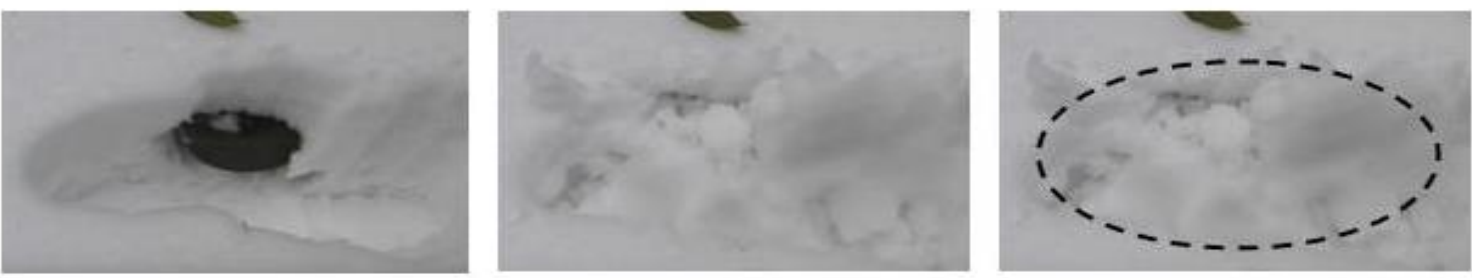

Рис. 4. Зображення установки міни ПМН-2 у сніг

Для розвідки мін за допомогою ВТЗР БПЛА необхідно визначити їхні інформаційні властивості. Для мін характерними будуть як відбиті, так і випромінювані сигнали, що проходять через “вікна прозорості” атмосфери (рис. 5) і можуть бути зареєстровані ВТЗР БПЛА.

Джерелом відбитого сигналу від міни за умов часткового або повного знаходження корпусу міни у незамаскованому вигляді (прямі розпізнавальні ознаки - форма, тон, колір, розміри) може бути сонячне випромінювання, що відбивається від корпусу міни на ландшафті, де вона встановлена.

Відбите поверхнею міни сонячне випромінювання може бути зареєстроване у видимому та ближньому інфрачервоному (через нагрів поверхні корпуса міни) діапазонах. У діапазоні $\lambda=0,38 \ldots 0,76$ мкм функціонують оптичні сенсори (оптико-електронні цифрові камери, багатоспектральні оптико-електронні сканери тощо) і людський зір, а також є три “вікна прозорості” в інфрачервоному діапазоні: два вузьких поблизу 3 і 5 мкм і одне порівняно широке в інтервалі приблизно від 8 до 14 мкм (інфрачервона оптико-електронна апаратура) [24].

До того ж треба зазначити, що коефіцієнт прозорості атмосфери залежить як від спектрального діапазону випромінювання, що використовується, так і від різних параметрів стану атмосфери (вмісту аерозолів, водяного пару та інших газових складових) [2]:

$$
\tau=\exp \left(-\alpha^{\prime} H_{n}\right)
$$

де $\tau$ - коефіцієнт прозорості атмосфери;

$\alpha^{\prime}$-коефіцієнт ослаблення потоку випромінювання унаслідок турбулентності атмосфери;

$H_{n}$ - наведена висота аерозйомки. 


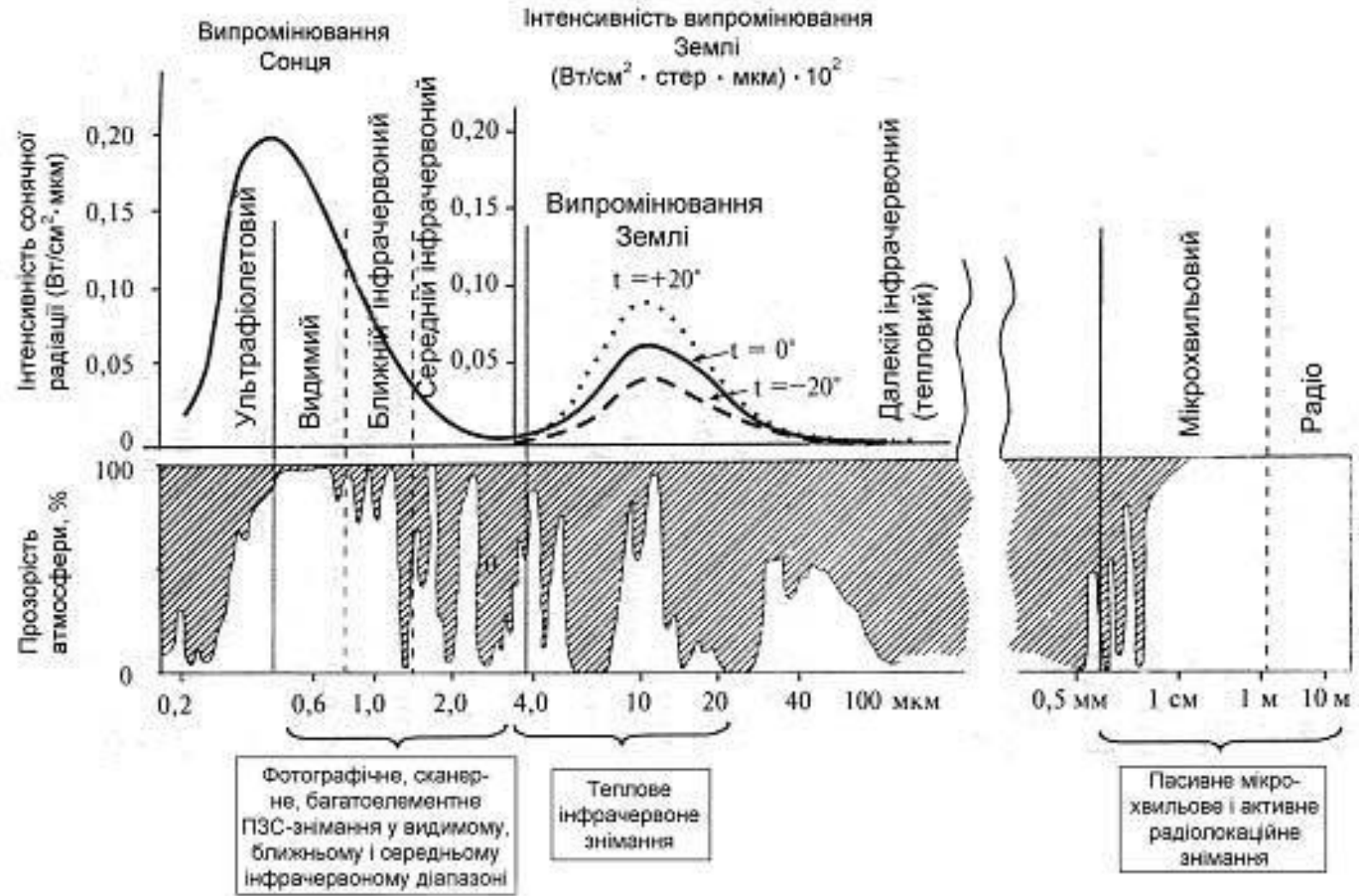

\section{Рис. 5. Вікна прозорості атмосфери і діапазони аерозйомки [3]}

Аналіз образу мини за їі зображенням на цифрових аерознімках під час дешифрування залежатиме від яскравості, кольору, розміру та геометричної форми. Отже умовою виявлення та розпізнавання міни за ії зображенням буде наявність контрасту $K$ яскравості на зображенні між міною (об'єктом) та ландшафтом (фоном), на якому міна встановлена (див. рис. 2, 3) [2, 3].

Усі контрасти за яскравістю знаходяться у межах $0 \ldots 1$ :

$$
K=\frac{B_{\max }-B_{\min }}{B_{\max }},
$$

де $B_{\max }, B_{\min }$ - максимальна і мінімальна яскравості між ландшафтом і міною.

При $K=0 \quad-$ ситуація відсутності контрасту - міну на зображенні не можливо виявити. Для $K=1$ - ситуація максимального контрасту - міну за іiі зображенням на цифровому аерознімку можна розпізнати до типу за прямими ознаками. Граничне значення контрасту $K$ для виявлення міни за іiі зображенням на аерознімку знаходиться в діапазоні $0,3 \ldots 0,6$. При $K \leq 0,2$ міна не буде помітна на зображенні. При $K=0,2 \ldots 0,3$ міна слабо помітна на зображенні. За умов $K>0,6$ міна добре помітна на зображенні [2].

Використання ВТЗР для $\lambda=0,38 \ldots 0,76$ обмежується денним часом і початком сутінок.
Наявність теплового контрасту між міною i ландшафтом, y якому вона встановлена, дає змогу вести розвідку мін у денний час, у значних сутінках і вночі.

Під час нагріву міни сонячним випромінюванням створюється іiі власне теплове випромінювання, що дає змогу це використовувати для аерозйомки у ближній $(\lambda=0,76 \ldots 3$ мкм $), \quad$ середній $\quad(\lambda=3 \ldots 5$ мкм $) \quad$ i дальній $\quad(\lambda=8 \ldots 14$ мкм $) \quad$ областях інфрачервоного діапазону випромінювання $[2,5]$.

Як відомо 3 теорії теплотехніки [6], інтенсивність випромінювання значно залежатиме від температури міни, як об'єкта випромінювання у незамаскованому або частково замаскованому вигляді:

$$
E_{\text {в }}=\varepsilon \sigma T^{4}
$$

де $E_{6}$ - інтегральна випромінювальна здатність; $\varepsilon$ - коефіцієнт випромінювальної здатності матеріалу корпуса міни;

$\sigma$ - постійна Стефана-Больцмана;

$T$ - температура матеріалу корпуса міни.

Максимальна різниця температур $\Delta T$ (тепловий контраст) між матеріалом корпуса міни та ландшафтом унаслідок нерівномірної швидкості їх нагрівання енергією сонячного випромінювання має місце в ранкові часи та у процесі охолодження у вечірні часи весняного та літнього періодів, а також на початку осені $[7,8]$. 
Щодо ландшафтів, на яких встановлюються міни, слід зазначити результати досліджень низки фахівців [2-4], які показали, що коефіцієнти яскравості та випромінювання грунтів i гірських порід залежать від температури, вологості, структури поверхні та їх складу. Для рослинного покриву інтенсивність власного випромінювання залежить від його термодинамічної температури.

Для забезпечення максимального контрасту в сучасних умовах активно застосовується спектрозональна аерозйомка у видимому діапазоні довжин хвиль $\lambda$ електромагнітного спектра, коли відбувається одночасне отримання цифрових знімків об'єкта в різних зонах видимого діапазону (Табл. 1).

Таблиця 1

Спектральні діапазони довжин хвиль видимого спектра

\begin{tabular}{|l|c|}
\hline \multicolumn{1}{|c|}{ Колір } & Діапазон довжин хвиль, мкм \\
\hline Фіолетовий & $0,38-0,44$ \\
\hline Синій & $0,44-0,48$ \\
\hline Блакитний & $0,48-0,50$ \\
\hline Зелений & $0,50-0,56$ \\
\hline Жовтий & $0,56-0,59$ \\
\hline Помаранчевий & $0,59-0,62$ \\
\hline Червоний & $0,62-0,76$ \\
\hline
\end{tabular}

Спектральні характеристики об'єктів фактично є їх розпізнавальною ознакою. Потік енергії доцільно реєструвати в тому діапазоні, який найбільш різко виокремлює досліджуваний об’єкт, тобто там, де він має специфічну спектральну яскравість.
Це обумовлюється тим, що більшість земних поверхонь та матеріалів відбивають i поглинають сонячний потік випромінювання вибірково, що підтверджується результатами низки наявних досліджень (рис. 6) [2, 3].

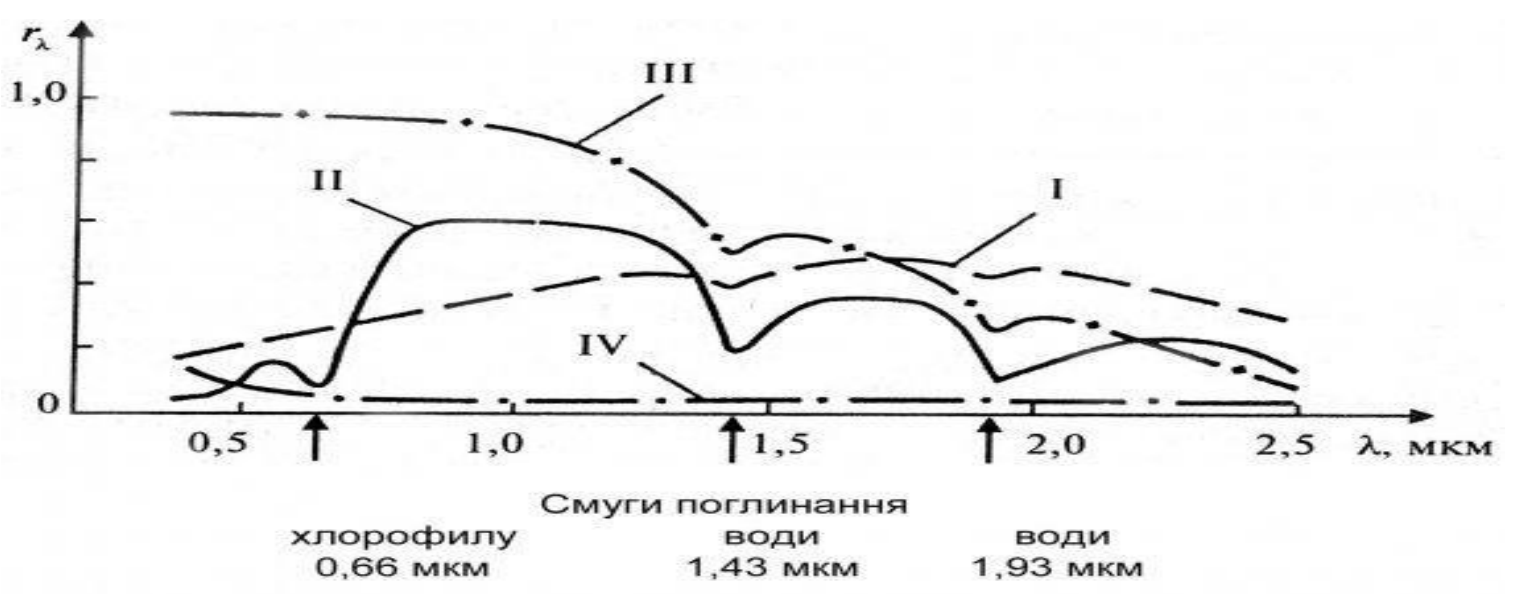

Схематизовані криві спектральної яскравості основних
класів природних об'єктів:
I- - гірські породи і ґрунти; II - рослинний покрив;
III - сніжний покрив; IV - водяні поверхні

Рис. 6. Схематизовані криві спектральної яскравості основних класів природних об'єктів [3]

Як видно зі схематизованих кривих рис. 6 спектрометрами в польових i лабораторних максимум спектральної яскравості снігу умовах. Основне призначення спектральних приходиться на діапазон $\lambda=0,38 \ldots 0,76$ мкм; бібліотек - візуальне або автоматичне максимум спектральної яскравості грунтів порівняння кривих спектральної відбивної знаходиться у діапазоні $\lambda=1,76 \ldots 1,8$ мкм; здатності різних об'єктів для виявлення максимум спектральної яскравості рослинного характерних зон поглинання (відбиття) енергії покрову знаходиться у діапазоні та використання добутої інформації під час $\lambda=0,76 \ldots 1,0$ мкм.

На сьогодні існують спектральні бібліотеки, що являють собою набори графіківкривих спектральної відбивної здатності проведення спектрального аналізу.

Використання даних спектральних бібліотек як еталонів під час проведення спектрального аналізу для виявлення об'єктів об'єктів, отримані багатоканальними 
на конкретному аерознімку потребує дотримання низки обов'язкових вимог [9-10].

Однакові одиниці виміру. Оскільки спектральні бібліотеки містять інформацію про значення коефіцієнтів відбиття на поверхні землі, що визначаються, як правило, у частках одиниці, яскравості пікселів мають бути приведені до такого ж вигляду, тобто має бути виконаний перерахунок яскравості пікселів у коефіцієнт відбиття (значення 0-1) і усунуто вплив атмосфери.

Однаковий спектральний діапазон $i$ розрізнення даних. Спектральний діапазон i розрізнення бібліотек відповідають характеристикам спектрометра. Спектральний діапазон більшості бібліотек спектрів від 0,2-0,4 до 14-25 мкм із розрізненням від 1 до декількох нанометрів, тобто, у бібліотеці може мати кілька сотень, а то і тисяч точок для побудови однієї кривої. Спектральне розрізнення багатозональних знімальних аеросистем непорівнянне 3 такими даними, що потребує перерахунку діапазону i розрізнення спектральної бібліотеки під конкретну знімальну аеросистему.

На сьогодні існує кілька загальнодоступних спектральних бібліотек: USGS Digital Spectral Library, JPL (Jet Propulsion Lab) spectral library, Johns Hopkins University Spectral Library [11-13].

Для наявного арсеналу мін необхідно провести окремі дослідження для побудови власних кривих спектральної яскравості для різних атмосферних умов, пори року й умов освітлення 3 подальшим створенням відповідної спектральної бібліотеки. Зазначені дослідження $\epsilon$ окремим напрямом наукових досліджень.

Для розпізнавання міни ПМН-2 в незамаскованому або частково замаскованому вигляді, коли форму, розмір, тон або колір міни можна використовувати як прямі ознаки для iii виявлення за іiі зображенням на цифровому аерознімку із застосуванням ВТЗР БПЛА, модель сигнатур, наприклад, для умови, коли міна знаходиться на грунті в літній період року, може бути формалізована у загальному вигляді 3 урахуванням (1) так:

$$
Q_{\Pi М H-2}=f\left(X_{1}, X_{2}\right)
$$

де $X_{1}-\lambda=0,38 \ldots 0,76$ мкм (міна знаходиться на фоні грунту в денний час);

$X_{2}-\lambda=3 \ldots 5$ мкм (міна знаходиться на фоні грунту в денний, вечірній і нічний часи).

Для деталізації змісту (5) потребується, як було зазначено, провести окремі наукові дослідження спектральних характеристик корпусу міни ПМН-2 на різних фонах, що дасть змогу за умов використання спектрозональної зйомки визначити такі спектральні інформаційні канали, використання яких забезпечить максимум контрасту на цифровому аерознімку між міною та ландшафтом, на якому вона знаходиться.

До того ж треба враховувати рівень освітленості протягом дня, оскільки змінюється альбедо як міни, так і ландшафту при зміні кута нахилу сонця протягом дня в різні пори року, що безпосередньо впливатиме на планування i ведення розвідки мін із застосуванням ВТЗР БПЛА.

В умовах маскування міни ПМН-2 під грунт, рослинність чи сніг прямі розпізнавальні ознаки міни (форма, розмір, тон або колір міни) відсутні, але має місце непряма (демаскуюча) розпізнавальна ознака - межа контуру лунки на місцевості, де встановлена міна, тобто має місце порушення структури грунтового, рослинного чи снігового покриву.

В умовах тривалого перебування міни в грунті (снігу) за умов зміни погодних i температурних умов, а також 3 урахуванням часу року та доби, 3'являються демаскуючі ознаки: просадка грунту в місцях встановлення мін, відмінність зовнішнього вигляду маскувального шару над міною від загального фону навколишньої місцевості тощо.

Демаскуючою ознакою міни є різниця температур $\Delta T$ маскувального шару грунту (рослинності на грунті) над міною і загального фону навколишнього ландшафту унаслідок нерівномірного ї нагрівання сонячною енергією в ранковий час $\mathrm{i}$ в процесі охолодження у вечірній час весняного та літнього періодів, а також на початку осені.

В умовах маскування міни i наявності сукупності демаскуючих ознак виявлення міни можливо 3 використанням кількох різних діапазонів довжин хвиль електромагнітного випромінювання.

Модель сигнатур, наприклад, для умови, коли міна встановлена у грунті 3 рослинним покровом у літній період року та замаскована, може бути формалізована у загальному вигляді 3 урахуванням (1) так:

$$
Q_{\text {ПмН-2,маск }}=f\left(X_{1}, X_{2}\right),
$$

де $X_{1}-\lambda=0,76 \ldots 1,0$ мкм (контур мін на грунті 3 рослинним покриттям у денний час);

$X_{2}-\lambda=3 \ldots 5$ мкм (контур міни у денний, вечірній і нічний часи).

Для підвищення достовірності результатів розвідки мін можуть бути використані дані від параметричних ТЗПР БПЛА, якщо такі будуть встановлені на БПЛА паралельно з ВТЗР БПЛА. 
У такому разі для мін характерними будуть відбиті сигнали, що можуть бути зареєстровані параметричними ТЗПР БПЛА.

Так, додаткова інформація щодо виявлення мини ПМН-2 під час ii маскування можливо отримати за допомогою фіксації відмінності діелектричної проникності вибухової речовини, матеріалу корпусу міни i ландшафту, де встановлена міна (грунт, сніг, вода), в ультрависокочастотному діапазоні радіохвиль (600 МГц і 800 МГц). На такому принципі функціонують радіохвильові міношукачі РBM-2 і PBM-2M [14], що знаходяться на озброєнні ЗС України.

Висновки. Запропоновано методичний підхід до побудови моделі сигнатур мін для видових технічних засобів повітряної розвідки, які дають змогу визначати спектральні характеристики як відбитих, так i випромінюваних сигналів, що проходять через "вікна прозорості" атмосфери у визначених секторах, від мін і ландшафту, на якому вони встановлені. Використання методичного підходу дасть змогу розробити технічні вимоги до безпілотного літального апарата розвідки мін та його корисного навантаження у вигляді апаратури видової розвідки в інтересах 3С України і ДПС України.

Напрями подальших досліджень. Подальші дослідження можуть відбуватися за напрямом побудови аналогічних моделей для параметричних засобів повітряної розвідки мін 3 використанням безпілотного літального апарата.

\section{СПИСОК ВИКОРИСТАНОЇ ЛІТЕРАТУРИ}

1. Кліщук Л. Земля 3 мін. Якою ціною Україна розміновує Донбас. URL: https://novynarnia. com/2019/04/26/rozminuvannia-donbasu/ звернення: 10.03.2019).

2. Меньшаков Ю. К. Основы защиты от технических разведок: учебное пособие; под общ. ред. М. П. Сычева. Москва: Изд-во МГТУ им. Н. Э. Баумана, $2011.478 \mathrm{c}$.

3. Моделі та спектральні характеристики об'єктів аерокосмічного зондування. URL: https://studopedia.su/11_3247_modeli-ta-spektralniharakteristiki-obiektiv-aerokosmichnogozonduvannya.html (дата звернення: 12.06.2019).

4. Бурштинська Х. В., Станкевич С. А. Аерокосмічні знімальні системи: навч. посібник. Львів: Львівська політехніка, 2010. 292 с.

5. Ллойд Дж. Системы тепловидения; пер. с англ. Н. В. Васильченко; под ред. А. И. Горячева. Москва: Мир, 1978.414 с.

6. Дементий Л. В., Авдеенко А. П. Краткий курс лекций по дисциплине “Теоретические основы теплотехніки": учеб. пособие. Краматорск : ДГМА, 2000. $180 \mathrm{c}$

7. Карпович И. Н. Военное дешифрирование аэроснимков. Москва : Воениздат, 1990. 544 с.

8. Вельцер В. Аэроснимки в военном деле; пер. с нем. Л. А. Молчановой. Москва: Воениздат, 1990. 288 с.

9. Jensen J.R. Remote Sensing of the Environment: An Earth Resource Perspective. NJ, Prentice Hall, 2000, 544 p.

10. Спектральные библиотеки - источники данных по спектрам. URL: http:/gis-lab.info/qa/spectrum-lib.html (дата звернення: 12.06.2019).

11. USGS Digital Spectral Library. URL: https://www.usgs.gov/labs/ spec-lab (дата звернення: 12.06.2019).

12. JPL (Jet Propulsion Lab) spectral library. URL : https://speclib.jpl.nasa.gov/ documents/jpl_desc (дата звернення: 12.06.2019).

13. Johns Hopkins University Spectral Library. URL: https://speclib.jpl.nasa.gov/ documents/jhu_desc (дата звернення: 12.06.2019).

14. Устройство и принцип работы миноискателя РВМ2M. URL: http://the-mostly.ru/misc/ustroystvo _i_printsip _ raboty_minoiskatelya_rvm_2.html (дата звернення 12.06.2019).

Стаття надійшла до редакційної колегії 18.10.2019

Нероба B. P.

Национальная академия Государственной пограничной службы Украины имени Богдана Хмельницкого, Хмельницкий

\section{Модель сигнатур мин для видовых средств воздушной разведки}

Резюме. В статье предложен методический подход к построению модели сигнатуры мин для видовых технических средств воздушной разведки, что позволяет определять сектора спектрального диапазона как отраженных, так и излучаемых сигналов от мин и ландшафта, на котором они установлены, проходящих через “окна прозрачности" атмосферы и которые могут быть зарегистрированы видовыми техническими средствами разведки беспилотного летательного аппарата.

Ключевые слова: мина; сигнатура; воздушная разведка; беспилотный летательный аппарат.

\section{Neroba}

National Academy of the State Border Guard Service of Ukraine named after Bogdan Khmelnitsky, Khmelnitsky

\section{Model of mines signatures for specific types of aerial reconnaissance equipment}

Resume. The article proposes a methodical approach to the construction of land mine signature model for specific aerial survey equipment, which allows to determine the spectral range sectors of both reflected and emitted signals from mines and the landscape on which they are installed, which pass through the "transparency windows" of the atmosphere and can be registered with the specific technical means of reconnaissance of the unmanned aerial vehicle.

Keywords: mine; signature; aerial reconnaissance; unmanned aerial vehicle. 